\title{
Research on Application of Big Data in Local Government Debt Audit
}

\author{
Xuefeng $\mathrm{Li}^{1, \mathrm{a}}$ \\ ${ }^{1}$ Department of Economics and Management, Longdong college, Gansu Qingyang, China
}

\begin{abstract}
While big data provides massive information for auditing work, it also changes the specific requirements of audit procedures. The pressure of economic downward has increased the concealment of local government debt risks in China, hence the requirements for its audit have increased accordingly. This paper combines the method of investigation and theoretical analysis to study the status quo of local government debt. Based on big data, the audit procedure of local government debt is designed in order to provide a reference for actual government debt audit work.
\end{abstract}

\section{Introduction}

The application of big data, which has been extended to many aspects of the field of economic management, can not only provide accurate and diverse data quickly, but also analyze the intrinsic relevance of data in different fields to connect the varied data, thus providing a powerful technical support for economic management [1]. In the "13th Five-Year Plan" audit work development plan, the National Audit Office clearly proposed to "expand the application of big data technology and explore multi-dimensional and intelligent big data audit analysis methods". Therefore, the widespread application of big data in auditing is not only an inevitable product of intelligent information processing, but also an effective way to improve the actual effect of audit work [2]. The contradiction between revenue and expenditure in local governments' financial operations has been increasing, which made the risk of government debt a social focus. The audit quality of local government debt directly affects the security of government debt. Studying the issue of local government debt auditing from the perspective of big data will help improve the quality of audits, complete the debt supervision system, and standardize the economic behavior of local governments.

Foreign research results on big data audit are few and the fields are scattered. The main research is about the impact of this idea on the macro level, i.e. audit philosophy, technology, function, timeliness, etc., but the research on its application in actual audit work is insufficient. In addition, the relevant research results are quite abundant in China. Since 2015, cnki.net has included 1,872 journal articles, whose research direction is mainly on qualitative issues such as audit concept change, method adjustment, and platform construction in the era of big data. There are few research results on the micro level of the big data audit. It is also rare to see the application of big data in specific audit work. While big data technology provides a large amount of business data for local government debt audits, virtualized data also complicates the audit environment [3]. How local government debt audits effectively use big data technology to prevent and resolve debt risks and ensure safe economic operation under the new normal has important strategic significance and academic value.

\section{2 status quo of local government debt scale}

Mastering the scale and composition of local government debt is the basis for studying debt audits. Under the protection of good government credit, local governments use various financing platforms to raise debt capital extensively. At the end of 2007, the balance of local government debt in China was less than 5 trillion yuan. By the end of 2010, it had increased to 10.7 trillion yuan, with an average annual growth rate of $28.9 \%$; Eastern region debt was as high as $49.7 \%$ of total national debt, which was almost equivalent to the sum of the debt in the central and western regions.

The National Audit Office's national government debt audit results show that at the end of June $2013^{1}$, the balance of local government debt was 10.89 trillion yuan. The revision of Budget Law makes it clear that local governments can only borrow debt by issuing bonds. The scale of government bonds in the past five years is shown in Figure 1. Among them, the scale of bond issuance increased by $758.8 \%$ in 2015 year-on-year; in

\footnotetext{
${ }^{1}$ Data source: General Office of the Audit Office of the People's Republic of China, 2013 Audit Office Performance Report, August 2014.
} 
2016 , it increased by $58 \%$, but the total scale is the peak in the past five years; The size of bonds has gradually decreased in 2017 and 2018, mainly due to the decline in the size of replacement bonds, and new bonds still increased, whose size has exceeded the size of replacement bonds in 2018 for the first time.

The new Budget Law restricts the subject, purpose, and scale of local government borrowing, which effectively controls the scale of debt and optimizes the debt structure. From Table 1, it can be seen that the national government debt increased by an average of 744.7 billion yuan every year from 2014 to 2018 , with an average annual growth rate of only $4.5 \%$. The general debt balance accounted for about $60 \%$ in each year. Although the proportion of special debt balances is low, it has shown an upward trend since 2015, and the use of debt funds has become more standardized.

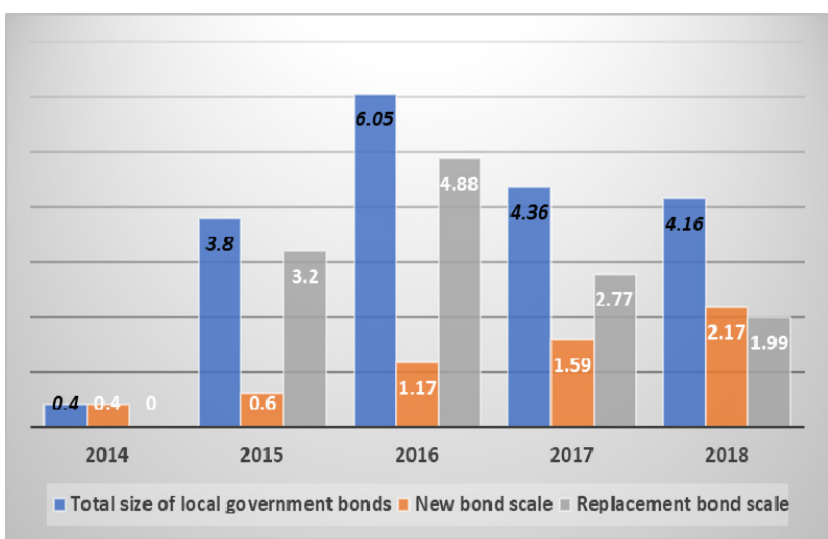

Figure 1. Column Chart of Local Government Bond Scale from 2014 to 2018 (Unit: Trillion Yuan)

Data source: National Bureau of Statistics website, Ministry of Finance website(Same as below)

TABle 1 Statistics of LOCAL GOVERnMENT DEBT FROM 2014 TO 2018

\begin{tabular}{l|l|l|l|l|l|l}
\hline \multirow{2}{*}{$\begin{array}{l}\text { Year } \\
\text { balance } \\
\text { (Billion } \\
\text { yuan) }\end{array}$} & \begin{tabular}{l} 
General debt \\
\cline { 2 - 6 }
\end{tabular} & $\begin{array}{l}\text { Balance } \\
\text { (Billion } \\
\text { yuan) }\end{array}$ & $\begin{array}{l}\text { Proportio } \\
\text { (\%) }\end{array}$ & $\begin{array}{l}\text { Balance } \\
\text { (Billion } \\
\text { yuan) }\end{array}$ & $\begin{array}{l}\text { Proportio } \\
\text { (\%) }\end{array}$ & $\begin{array}{l}\text { lebt } \\
\text { ratio( } \\
\text { \%) }\end{array}$ \\
\hline 2014 & 154074 & 94272 & 61.2 & 59802 & 38.8 & 24.2 \\
\hline 2015 & 154221 & 99272 & 64.4 & 54949 & 35.6 & 23.2 \\
\hline 2016 & 153164 & 97868 & 63.9 & 55296 & 36.1 & 19.8 \\
\hline 2017 & 164706 & 103322 & 62.7 & 61384 & 37.3 & 19.3 \\
\hline 2018 & 183862 & 109939 & 59.8 & 73923 & 40.2 & 20.4 \\
\hline
\end{tabular}

a. debt ratio is the ratio of the debt balance at the end of the year to the GDP of the current year. It is used to measure the total economic capacity of government debt or the degree of dependence of economic growth on government debt.

Comparation of the growth of local government debt and GDP is shown in Figure 2. In the past five years, China 's GDP has increased steadily, but the scale of local government debt has shown a U-shaped trend, making debt ratio fluctuate obviously. Due to the decline in government debt, the debt ratio in 2014-2016 shows a downward trend, and the ability to control debt risk has improved. Debt growth in 2017 and 2018 exceeded GDP growth. In particular, the debt growth rate in 2018 increased by $4.1 \%$ year-on-year, causing the debt ratio to increase by $1.1 \%$ over 2017 , which not only reversed the trend of the debt ratio but also increased the risk level of local government debt.

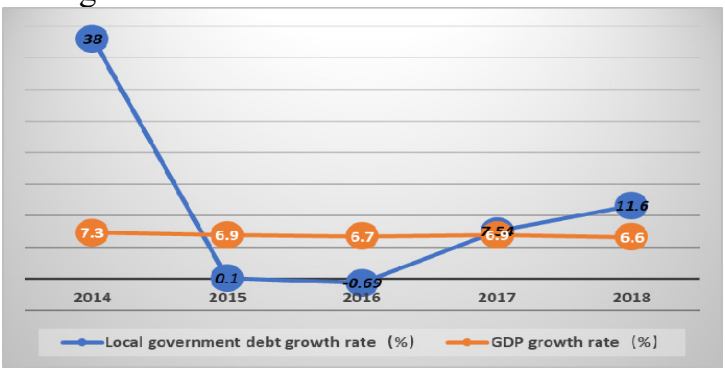

Figure 2. Line chart of local government debt and GDP growth from 2014 to 2018 (Unit:\%)
Affected by complex causes, information asymmetry, large amount of debt and other intrinsic characteristics, local government debt in China presents a series of characteristics, such as the high social attention of debt, lots of hidden factors of debt risk, inescapability of the potential risks of government bonds issuance, the hidden risks of bond replacement, and so on. Strengthening government debt audits can obtain debt stock data, reveal debt management omissions, verify debt financing and investment, and maintain government debt security.

\section{Design of local government debt audit process under the background of big data}

The audit process formulated by the National Audit Office covers the four stages of audit planning, audit preparation, audit implementation and audit termination ${ }^{2}$. This paper studies the issue of local government debt audit based on big data, following the design principles of objectivity, compliance, systematicness, and operability. Prior to the audit procedures prescribed by the Audit Commission, the risk assessment process of the auditees is performed, and the results of the risk assessment will be reflected in the audit report for effective audit rectification.

\footnotetext{
${ }^{2}$ Official website of the Audit Office of the People's Republic of China.
} 


\subsection{Risk assessment phase}

1) Work priorities. In this stage, the auditees' risk level is studied, the audit scope and audit objectives are determined, and the key points of the audit are locked [4]. The scope of local government debt audit based on big data technology should not be too large. The debt structure, debt type and investment direction should be considered in a unified manner, combined with government priorities, public concerns and auditing difficulties to determine the main factors of debt risk. And the level of debt risk is supposed to be accessed by influencing factor, in order to determine audit priorities accordingly. In this study, by in-depth interviews with personnel from the audit department and extensive verification of experts and scholars, the influencing factors of local government debt risk was designed (as shown in Figure 3).
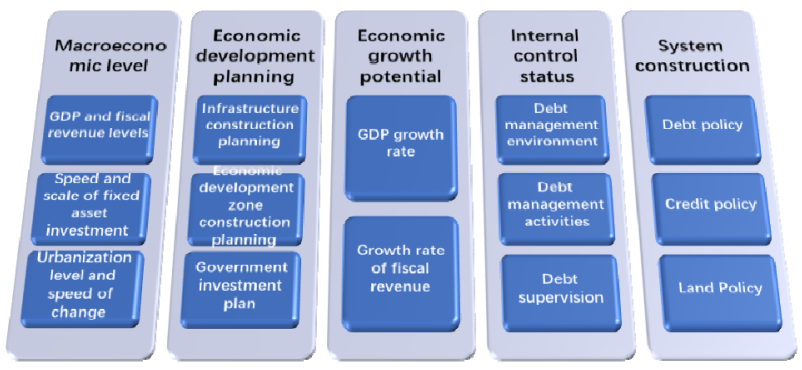

Figure 3. Major influencing factors of local government debt risk

2) Big data audit requirements. This stage mainly applies the powerful predictive function of big data technology. The systemic risk which may appear in government departments and debt platform can be identified by combining local economic operation and comparing with the indexes of budget and final accounts, financial status and cash flow, which are collected in the database. The actual indexes of the department which mainly use the debt fund is going to be compared with the indexes in database, in order to estimate the special risks of particular auditees. In order to identify the potential risks of government debt management, the Extensible Business Reporting Language (XBRL) function provided by financial software should be fully used. Its Internetbased, cross-platform operation realizes the integration and utilization of financial data, and facilitates financial report integration, financial data exchange and the acquisition of audit evidence.

\subsection{Audit planning phase}

1) Work priorities. When formulate the audit plan, the communication and cooperation of relevant departments and personnel should be emphasized first, and the pre-trial training should be arranged. Second, the start and end time of each stage should be reasonably arranged according to the workload to ensure that the audit task can be completed on time. Finally, according to audit task, the division of labor and audit responsibility should be clear. The audit plan should be formulated according to the obtaining, using and repaying of the fund of local government debt. If something new occurs during the implementation of the plan, such as debt risks and the changes of audit evidence, the original plan should be adjusted in time to ensure the integrity of the audit process.

2) Big data audit requirements. This stage should focus on not only the acquisition, integration and processing of multi-source heterogeneous big data but also the compression and storage of related data, as well as the fast transmission and calculation of big data in multi-domain and multi-layer. Meanwhile the application of big data in key links such as audit decision-making, risk management and control, and fault diagnosis should also be emphasized. Therefore, the audit procedure could be designed reasonably, and the audit power could be arranged thoughtfully, in order to ensure the completion of the audit plan.

\subsection{Audit implementation phase}

\subsubsection{Work priorities}

a) Collect audit evidence. First, auditors should use big data technology to obtain the first-hand information about government debt borrowing platforms, project construction, use benefits, and repayment guarantees. Second, data processing software such as EXCEL and SPSS should be used to statistically organize and preliminarily analyze relevant data to make the audit evidence methodized and systematic. Finally, data analysis software should be used to calculate investment evaluation indicators and study the feasibility of the project; compare financial data and do ratio analysis, check the use of debt funds; calculate the solvency index, and check the debt repayment ability of the debtor.

\section{b) Analysis of audit evidence.}

First, the sources and whereabouts of government debt funds should be analyzed. As for financing platform companies, the financial status, profitability, and solvency should be analyzed as a key point, based on corporate financial statement. As for local government bonds, Attention should be paid to whether the bond issuance scale is reasonable, whether the bond maturity date is too concentrated, whether interest can be repaid in time and in full, and the source of funding for principal repayment is guaranteed. The audit evidence of the funds occupied by public institutions such as infrastructure, municipal construction, education, and medical care focuses on analyzing the use of government debt funds. The analysis of funds occupied by construction projects should focus on the feasibility and practicality of the project, whether the project management system is sound, and the cost whether the control is strict and whether the construction risks are controllable. The analysis of the funds occupied by 
public institutions focuses on the economic benefits, social benefits and return of the funds.

Second, local government debt risks should be evaluated. According to the audit announcement of the National Audit Office, and after studying the documentation in cnki.net, this paper followed the concise and practical principles to construct a system of government debt risk evaluation index (see Table 2 for details). These indexes compare the total regional debt, maturity debt, debt interest etc. with fiscal revenue and expenditure, GDP, and other economic development indicators, in order to measure the rationality of debt scale and the degree of debt risk.

Drawing on the evaluation standards of developed countries and combining the results of government debt audits in China, this paper determined the critical values and alert values of key indicators to provide a reference for government debt risk measurement.

Table 2 Design Table of Local Government Debt Risk Evaluation Index System

\begin{tabular}{|c|c|c|c|c|}
\hline $\begin{array}{l}\text { comment } \\
\text { content }\end{array}$ & Index name & Calculation method & Index threshold & Index alert value \\
\hline \multirow{2}{*}{$\begin{array}{l}\text { Stock } \\
\text { risk }\end{array}$} & Debt burden ratio & Total debt / GDP & $25 \%$ & $20 \%$ \\
\hline & Debt settlement rate & $\begin{array}{c}\text { Total debt / financial } \\
\text { revenue }\end{array}$ & $150 \%$ & $100 \%$ \\
\hline \multirow{3}{*}{$\begin{array}{l}\text { Incremen } \\
\text { tal risk }\end{array}$} & Debt growth rate & $\begin{array}{c}\text { Increase in debt / total } \\
\text { debt }\end{array}$ & - & - \\
\hline & Debt dependency & $\begin{array}{l}\text { Debt income / financial } \\
\text { expenditure }\end{array}$ & - & - \\
\hline & Debt deficit ratio & Deficit / GDP & - & - \\
\hline \multirow{3}{*}{$\begin{array}{l}\text { Structura } \\
\text { l risk }\end{array}$} & Debt to maturity & Debt due / total debt & - & - \\
\hline & $\begin{array}{l}\text { Guaranteed debt } \\
\text { ratio }\end{array}$ & $\begin{array}{l}\text { Guaranteed debt } \\
\text { /financial revenue }\end{array}$ & $20 \%$ & $15 \%$ \\
\hline & Idle debt ratio & $\begin{array}{c}\text { Unused debt funds / } \\
\text { total debt }\end{array}$ & - & - \\
\hline \multirow{3}{*}{$\begin{array}{c}\text { Debt } \\
\text { service } \\
\text { risk }\end{array}$} & Debt service rate & $\begin{array}{l}\text { Debt service / financial } \\
\text { expenditure }\end{array}$ & $25 \%$ & $20 \%$ \\
\hline & Debt verdue ratio & $\begin{array}{l}\text { Overdue debt amount / } \\
\text { Due debt amount }\end{array}$ & $10 \%$ & $8 \%$ \\
\hline & Assets and liabilities & $\begin{array}{l}\text { Total Liabilities / Total } \\
\text { Assets }\end{array}$ & $60 \%$ & $100 \%$ \\
\hline
\end{tabular}

c) Draw audit conclusions. Based on the analysis results of audit evidence, the audit team forms preliminary audit opinions, obtains and analyzes further evidence of the disputed audit evidence, seeks experts opinions, and strives to be objective and truthful in the audit conclusions. Before the completion of the audit, the audit evidence should be sorted and stored properly.

\subsubsection{Big data audit requirements}

a) Big data collection requirements. First, define the scope of data collection. The data collection should mainly focus on the accounting and business activity data of the relevant organizations, as well as the network data associated with the organizations' cash flow. The data with large storage capacity and low use value should be avoided including into the collection scope. Second, enrich data acquisition methods. On the basis of obtaining the audit evidence of the data submission platform of each organization, the required information can also be loaded from the government affairs cloud, and specific data can be collected using API interfaces, Internet crawlers, remote sensing and other technologies. Third, ensure the authenticity and comprehensiveness of the data. From the national security perspective, data security must be a top priority [5]. The big data collection methods and data sources has been diversified developing, which will inevitably result in data errors and omissions. Hence, the data should be carefully screened and checked during data collection and use.

b) Big data use requirements. Big data makes it possible to apply various intelligent algorithms and visualization technologies. In the data analysis stage, the data structure should be optimized, simplified calculations should be carried out using structural relationships, and multi-granularity intelligent processing of big data should be performed. In order to prevent audit risks, the working experience of auditors should be used to explain and evaluate the model to achieve a balance between technology and experience, off-site analysis and on-site extension. For basic and public welfare project expenditure, economic and social benefits should be equally valued, the benefits of similar projects should be compared and evaluated extendedly during the analysis of audit evidence.

\subsection{Audit report phase}

1) Work priorities. First, the audit evidence should be fully reviewed before the audit report is formed. Special attention should be paid to the impact of objective circumstances such as national policies, financing platform companies' operating strategies, and project construction changes on debt risk. Audit evidence may be 
added if necessary. Second, according to the implementation situation, prepare audit work drafts, solicit opinions from the government and competent departments, and submit the final audit report. The audit report should include specific contents such as debt overview, management omissions, improvement suggestions, and department feedback.

2) Big data audit requirements. The application of big data at this stage is mainly focused on the review of audit evidence. In addition to emphasizing the authenticity and comprehensiveness of the data, it should also focus on new problems and situations, and require staff to have the ability to identify unintentional errors, intentional errors, and fabricated data. Audit institutions are required to standardize data acquisition processes and ensure the reliability of big data audit conclusions.

\subsection{Audit rectification phase}

1) Work priorities. According to the government debt management issues raised in the audit report, the government departments draw on the improvement suggestions and implement the rectification work. The audit team should combine on-site inspection and rectification report review to track and understand the rectification process and effectiveness of government debt, and urge the implementation of rectification measures. After field visit, the researcher found that some local governments have a fluke mentality and muddle through their audit opinions, making it difficult for limited debt management opinions to be effective. Therefore, it is recommended that the implementation of debt audit rectification be used as a quantitative assessment index for government officials to ensure the quality of audit rectification.

2) Big data audit requirements. Big data audit requires in-depth exploration of new models and new elements found in the audit process to form a new method system to guide government audits. Government departments should set up a special rectification team to lead and supervise the management of financing platforms, project construction, etc. in accordance with audit report requirements. For major risk points disclosed in the audit report, supervision should be strengthened to prevent government departments from making debt risks hidden and audits track difficult by concoct various pretexts and perpetrate a fraud.

\section{Conclusion}

Auditing is called the "immune system" of government debt management, which can effectively predict and prevent the risk of local government debt. Based on the analysis of the current scale of local government debt in China, this paper designs an audit process for local government debt based on big data technology, which benefits the improvement of the efficiency and quality of local government debt audits. However, due to the existence of potential and hidden risks of government debt, there are still many problems in auditing in terms of system construction and auditing methods. Promoting the construction of the laws and standards of government debt audit in the big data environment is the key to the future development of big data audits in China.

\section{References}

1. Chen Wei, Wally. "Electronic Data Audit in Big Data Environment: Opportunities, Challenges and Methods".Computer Science 2016 (1): 8-13.

2. Liu Guocheng, Chen Zhengsheng. Development Trend of Big Data Audit . Friends of Accounting. 2019 (8): 30-35.

3. Li Zhen. Thinking on the reform of government auditing in the era of big data. Finance and Accounting Newsletter. 2017 (28): 91-94.

4. Song Xiayun, Ma Yiliu, etc. Functional Cognitive Analysis of National Auditing in Local Government Debt Risk Management . Audit Research. 2016 (1): 45-52.

5. Liu Xing, Niu Yanfang, etc. Some Thoughts on Promoting Big Data Audit [J] .Audit Research.2016 (5): 3-7. 